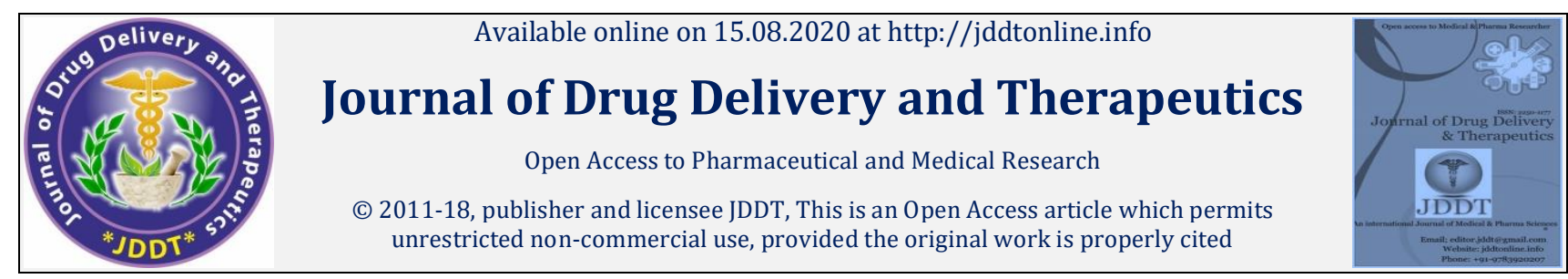

Open 1 Access

Research Article

\title{
Isolation and Characterization of Bioactive Components Derived from Whole Plant of Selaginella bryopteris
}

\author{
Abhilasha Jain*, Savita Shrivastava \\ *Department of Chemistry, Govt. Maharani Laxmi Bai Girls P.G. Autonomous College, Kamla Park Rd, Professors Colony, Bhopal, Madhya \\ Pradesh 462001, India
}

\begin{abstract}
Natural products and herbal remedies used in traditional folklore medicine have been the source of many medically beneficial drugs because they elicit fewer side effects, relatively cheap, affordable and claimed to be effective. However, in order to make these remedies acceptable to modern medicine, there is a need to scientifically evaluate them to identify the active principles and to understand their mechanism of action. Selaginella bryopteris ( $S$. bryopteris) is a pteridophytic plant belongs to the family selaginellaceae. Its familiar name is sanjeevani booti. The aim of the present investigation was isolation and characterization of active components derived from whole plant of $S$. bryopteris. The plant was extracted with petroleum ether, ethyl acetate and methanol solvent. The preliminary phytochemical results revealed that alkaloids, carbohydrates, reducing sugar, flavonoids, protein, amino acid, tannin and phenolic compound as active constituents in methanolic extract of $S$ bryopteris. The total phenolics content of whole plant of methanolic extract was $(184.13 \pm 0.416 \mathrm{mg} / \mathrm{gm})$, followed by flavonoids $(89.67 \pm 2.516 \mathrm{mg} / \mathrm{gm})$. The quantification and the identification of compounds in the crude extract and active bands isolated by preparative TLC were accomplished using spectroscopic analysis. The most important compounds amentoflavone identified in the crude extract appreciable amounts may account for its various biological activities.
\end{abstract}

Keywords: Selaginella bryopteris, Isolation, Plant extraction, Phytochemical

Article Info: Received 09 June 2020; Review Completed 18 July 2020; Accepted 26 July 2020; Available online 15 August 2020

Cite this article as:

Jain A, Shrivastava S, Isolation and Characterization of Bioactive Components Derived from Whole Plant of Selaginella Bryopteris, Journal of Drug Delivery and Therapeutics. 2020; 10(4-s):127-131 http://dx.doi.org/10.22270/jddt.v10i4s. 4255

*Address for Correspondence:

Abhilasha Jain, Department of Chemistry, Govt. Maharani Laxmi Bai Girls P.G. Autonomous College, Kamla Park Rd, Professors Colony, Bhopal, Madhya Pradesh 462001, India

\section{INTRODUCTION}

The use of plants and their constituents in primary health care has ancient history as old as human beings. Various medicinal plants have proven therapeutics implication in the health management via antioxidant, anti-inflammatory, antidiabetic, and other biological activities 1,2. S. bryopteris is a perennial, herbaceous lythophytic plant that grows in shallow soils on rocky outcrops of slopes of small hills in direct sunlight in humid tropical regions. It is a traditional herb that for centuries has occupied a prime place among the most sought-after herbs in Indian mythology as 'Sanjeevani' (one that infuses life) by virtue of its resurrection properties. The herb is popular among tribal people of India as a dietary supplement in treatment, signifying its role as a 'panacea' against varied maladies 3,4 . Several studies have explored the bioactive components contributing to the medicinal properties of varied species of Selaginella 5-10. In particular, the flavonoid-rich contents of this herb have demonstrated numerous and varied biological activities 11-14. In lieu of impressive epidemiological evidence for the cytoprotective effects of plant flavonoids and correlation of high flavonoid intake with a decreased risk of cancer. Amentoflavone $\left(\mathrm{C}_{30} \mathrm{H}_{18} \mathrm{O}_{10}\right)$ is a common biflavonoid chemically named as $8-[5-(5,7-$ dihydroxy4-oxo-4H-chromen-2-yl)-2-hydroxyphenyl]-5,7dihydroxy-2-(4-hydroxyphenyl)-4H-chromen-4-one, which naturally occurs in many plants. It is also considered as an apigenin dimer linked by a $\mathrm{C}_{3}-\mathrm{C}_{8}$ covalent bond. This compound was firstly isolated by Okigawa and his colleagues in 1971 from three plants of the Selaginella species (Selaginella tamariscina (Beauv.) Spring, Selaginella nipponica, and Selaginella pachystachys) 15. From then on, phytochemical researchers have isolated and identified this biflavonoid from more than 120 plants, some of which have been used as traditional folk medicines in many regions of the world for even thousands of years. With the development of modern pharmacology, more and more evidence has proved many of the bioactivities of amentoflavone, including anti-oxidant 16 , anti-inflammatory 
17, anti-senescence[18, anti-tumor 19, anti-virus 20, and antifungal 21 effects, as well as therapeutic effects on the central nervous system 22 and cardiovascular system 23 , etc. The purpose of this study is to identify and characterize the bioactive principles from the whole plant of $S$. bryopteris. In this paper, we report the isolation and characterization of known compounds from S. bryopteris namely amentoflavone.

\section{MATERIALS AND METHODS}

\section{Plant materials}

Whole plant of S. bryopteris was collected from Village Rainikheda and Tamiya, Dist. Chhindwara, (M.P.) India. Herbarium of plants species were prepared graciously and submitted to Department of Botany, Saifia College of Science, Bhopal India, for authentication. Plants were authenticated by Dr. Zia-Ul-Hasan, Head, Department of Botany, Safia College of Science, Bhopal, India. Plant authentication voucher numbers obtained were 391/Bot/Saifia/16 for $S$. bryopteris.

\section{Chemical reagents}

All the chemicals used in this study were obtained from $\mathrm{Hi}$ Media Laboratories Pvt. Ltd. (Mumbai, India), Sigma Aldrich Chemical Co. (Milwaukee, WI, USA), SD Fine-Chem. Ltd. (Mumbai, India) and SRL Pvt. Ltd. (Mumbai, India).All the chemicals used in this study were of analytical grade.

\section{Extraction}

Collected plant material washed under running tap water and kept in shade for drying. Dried plant materials were then powdered using blender and further observed for colour, odour, and texture then placed in packed labelled air tight container for further use. Plant material was extracted by continuous hot percolation method using Soxhlet apparatus 24 . Powdered material of $S$. bryopteris was placed in thimble of soxhlet apparatus. Soxhlation was performed at $60^{\circ} \mathrm{C}$ using petroleum ether as non-polar solvent. Exhausted plant material (marc) was dried and afterward re-extracted with ethyl acetate and methanol solvent. For each solvent, soxhlation was continued till no visual colour change was observed in siphon tube and completion of extraction was confirmed by absence of any residual solvent, when evaporated. Obtained extracts was evaporated using rotary vacuum evaporator (Buchi type) at $40^{\circ} \mathrm{C}$. Dried extract was weighed and percentage yield for each extract was determined.

\section{Qualitative phytochemical analysis of plant extract}

The S. bryopteris whole plant extract obtained was subjected to the preliminary phytochemical analysis following standard methods 25,26 . The extract was screened to identify the presence or absence of various active principles like phenolic compounds, carbohydrates, flavonoids, glycosides, saponins, alkaloids, fats or fixed oils, protein and amino acid and tannins.

\section{Quantification of secondary metabolites}

Quantitative analysis is an important tool for the determination of quantity of phytoconstituents present in plant extracts. For this TPC and TFC are determined. Extracts obtained from whole plant of $S$. bryopteris plant material of subjected to estimate the presence of TPC and TFC by standard procedure.

\section{Total phenolic content estimation}

The amount of total phenolic in extracts was determined with the Folin Ciocalteu reagent. Concentration of (20-
$100 \mu \mathrm{g} / \mathrm{ml}$ ) of gallic acid was prepared in methanol. Concentration of $100 \mu \mathrm{g} / \mathrm{ml}$ of plant extract were also prepared in methanol and $0.5 \mathrm{ml}$ of each sample were introduced in to test and mixed with $2 \mathrm{ml}$ of a 10 fold dilute folin Ciocalteu reagent and $4 \mathrm{ml}$ of $7.5 \%$ sodium carbonate. The tubes were covered with parafilm and it was then incubated at room temperature for $30 \mathrm{~min}$ with intermittent shaking and the absorbance were taken at $765 \mathrm{~nm}$ against using methanol as blank. Total phenolic content was calculated by the standard regression curve of gallic acid and the results were expressed as gallic acid equivalent $(\mathrm{mg} / \mathrm{g})$ 27.

\section{Total flavonoid content estimation}

Different concentration of rutin (20 to $100 \mu \mathrm{g} / \mathrm{ml}$ ) was prepared in methanol. Test sample of near about same polarity $(100 \mu \mathrm{g} / \mathrm{ml})$ were prepared. An aliquot $0.5 \mathrm{ml}$ of diluted sample was mixed with $2 \mathrm{ml}$ of distilled water and subsequently with $0.15 \mathrm{ml}$ of a $5 \% \mathrm{NaNO}_{2}$ solution. After 6 min, $0.15 \mathrm{ml}$ of a $10 \% \mathrm{AlCl}_{3}$ solution was added and allowed to stand for $5 \mathrm{~min}$, and then $2 \mathrm{ml}$ of $4 \% \mathrm{NaOH}$ solution was added to the mixture. The final volume was adjusted to $5 \mathrm{ml}$ with distilled water and allowed to stand for another $15 \mathrm{~min}$. Absorbance was determined at $510 \mathrm{~nm}$ against water as blank. Total flavonoid content was calculated by the Standard regression curve of Rutin/ Quercetin 27.

\section{Isolation of sitosterol by preparative TLC}

\section{Preparation of stationary phase}

Readymade silica gel GF 254 plates with a layer thickness of $0.25 \mathrm{~mm}$, dimension $20 \mathrm{~cm} \times 20 \mathrm{~cm}$. The plates were reactivated by heating in the oven at $100^{\circ} \mathrm{C}$ for $15 \mathrm{~min}$, left to cool, and used for application after allocation of the baseline and the solvent front.

\section{Preparation of solvent system}

Mobile phase for biflavonoid, chloroform-methanol 75:25 (v/v) was mixed in a conical flask and introduced in the jar. The jar was lined with a filter paper, closed tightly, and left for saturation.

\section{Spectroscopic characterization}

Different spectroscopic methods were used to elucidate the structure of isolated compound. Among the spectroscopic techniques IR, ${ }^{1} \mathrm{H}-\mathrm{NMR}$ and MASS were carried out. The IR spectrum was recorded on FTIR Perkin Elmer, $1 \mathrm{H}-\mathrm{NMR}$ and spectra were recorded using CDCl3 as solvent on Bruker Advance II 400 NMR spectrometer from RGPV, University, Bhopal mass spectra were recorded at high resolution on a mass spectrometer (Perkin Elmer Auto system) at Sophisticated Instrumentation centre for Indian Institute of Science Education and Research (IISER) Bhopal, Madhya Pradesh, India and the data are given in $\mathrm{m} / \mathrm{z}$ values.

\section{RESULTS AND DISCUSSIONS}

The crude extracts so obtained after each of the successive soxhlation extraction process were concentrated on water bath by evaporation the solvents completely to obtain the actual yield of extraction. The yield of extracts obtained from the whole plants of the $S$. bryopteris using petroleum ether, ethyl acetate and methanol as solvents are depicted in the Table 1 . The petroleum ether, ethyl acetate and methanol extract of $S$. bryopteris was subjected to screening for its phytochemical constituents. The phytochemical screening results are shown in Table 2. The methanolic extracts containing alkaloids, carbohydrates, reducing sugar, flavonoids, protein, amino acid, tannin and phenolic. 
Quantitative phytochemical assay was performed by calculating total phenolic content (TPC) and total flavonoid content (TFC). The TPC was calculated with respect to gallic acid (standard) and TFC was then calculated with respect to rutin taken as standard. The TPC and TFC in methanolic extract were found to be $184.13 \pm 0.416 \mathrm{mg} / \mathrm{gm}$ and $89.67 \pm 2.516 \mathrm{mg} / \mathrm{gm}$ respectively table $3 \&$ fig 1,2 .

During extraction, solvents methanol extract of the plant was investigated by TLC which revealed the presence of amentoflavone that appeared as spot in mobile phase (chloroform: methanol) against amentoflavone reference standard, and the spot of extract appeared the same Rf value as that in reference standard on TLC plate as shown in Table 4 , as indicated by the development of violet spots after spraying by vanillin-sulfuric acid spray reagent [13]. The IR (KBr) absorption spectrum (Fig. 3) showed absorption peaks: $v$ 3244, 3188, 3148 (Broad peak of OH), 1685 (Aromatic C=C), 1604, 1556,1508 $\mathrm{cm}^{-1}$ 1HNMR (Fig.4) ${ }^{1} \mathrm{HNMR}\left(500 \mathrm{MHz}, \mathrm{CD}_{3} \mathrm{OD}\right): \delta 8.80(\mathrm{~d}, \mathrm{~J}=5.5,1 \mathrm{H}), 7.83(\mathrm{~m}$, $2 \mathrm{H}), 7.10(\mathrm{~m}, 2 \mathrm{H}), 6.88(\mathrm{~s}, 1 \mathrm{H}), 6.38(\mathrm{~d}, \mathrm{~J}=4.5,1 \mathrm{H}) 6.03(\mathrm{~d}$, $\mathrm{J}=10,1 \mathrm{H}), 4.91$ (s, 1H). HRMS $m / z=538 \mathrm{M}^{+}$(Fig. 5).

Table 1: Results of percentage yield of extracts

\begin{tabular}{|c|c|c|c|}
\hline Plant Name & \multicolumn{3}{|c|}{ Percentage yield (\%) } \\
\hline & Pet. Ether & Ethyl acetate & Methanol \\
\hline S. bryopteris & 1.48 & 2.67 & 2.49 \\
\hline
\end{tabular}

Table 2: Phytochemical evaluation of $S$. bryopteris extract

\begin{tabular}{|c|c|c|c|c|}
\hline \multirow{2}{*}{ S. No. } & \multirow{2}{*}{ Experiment } & \multicolumn{3}{|c|}{ Result (SB) Extract } \\
\hline & & Pet. ether & Ethyl acetate & Methanolic \\
\hline \multicolumn{5}{|l|}{ 1. Alkaloids } \\
\hline 1.1 & Mayer's reagent test & -ve & -ve & + +ve \\
\hline 1.2 & Wagner's reagent test & -ve & -ve & + +ve \\
\hline 1.3 & Hager's reagent test & -ve & -ve & $+\mathrm{ve}$ \\
\hline \multicolumn{5}{|c|}{ 2. Carbohydrates } \\
\hline 2.1 & Molish's test & -ve & $+\mathrm{ve}$ & $+\mathrm{ve}$ \\
\hline 2.2 & Barfoed's test & -ve & $+\mathrm{ve}$ & $+\mathrm{ve}$ \\
\hline \multicolumn{5}{|c|}{ 3. Test for Reducing Sugar's } \\
\hline 3.1 & Fehling's test & -ve & -ve & $+\mathrm{ve}$ \\
\hline 3.2 & Benedict's test & -ve & -ve & $+\mathrm{ve}$ \\
\hline \multicolumn{5}{|c|}{ 4. Flavonoids } \\
\hline 4.1 & Alkaline reagent test & -ve & + +ve & + ve \\
\hline 4.2 & Shinoda test & -ve & $+\mathrm{ve}$ & $+\mathrm{ve}$ \\
\hline 4.3 & Lead acetate test & -ve & $+\mathrm{ve}$ & $+\mathrm{ve}$ \\
\hline \multicolumn{5}{|l|}{ 5. Glycoside } \\
\hline 5.1 & Borntrager test & -ve & $+\mathrm{ve}$ & -ve \\
\hline 5.2 & Legal's test & -ve & $+\mathrm{ve}$ & -ve \\
\hline 5.3 & Killer- Killiani test & -ve & $+\mathrm{ve}$ & -ve \\
\hline \multicolumn{5}{|c|}{ 6. Tannin and Phenolic compound } \\
\hline 6.1 & Ferric chloride test & -ve & $+\mathrm{ve}$ & $+\mathrm{ve}$ \\
\hline 6.2 & Lead Acetate test & -ve & $+\mathrm{ve}$ & $+\mathrm{ve}$ \\
\hline 6.3 & Dilute Iodine solution & -ve & $+\mathrm{ve}$ & + ve \\
\hline \multicolumn{5}{|l|}{ 7. Saponin } \\
\hline 7.1 & Faom Test & -ve & -ve & -ve \\
\hline \multicolumn{5}{|c|}{ 8. Test for Proteins and amino acid } \\
\hline 8.1 & Ninhydrin test & -ve & -ve & $+\mathrm{ve}$ \\
\hline \multicolumn{5}{|c|}{ 9. Test for Triterpenoids and Steroids } \\
\hline 9.1 & Salwonski Test & -ve & -ve & -ve \\
\hline 9.2 & Libberman-Burchard's & -ve & -ve & -ve \\
\hline
\end{tabular}


Table 3: Total phenolic and flavonoid content of extracts

\begin{tabular}{|c|c|}
\hline Test & Methanolic extract \\
\hline TPC & $184.13 \pm 0.416 \mathrm{mg} /$ gm equivalent to Gallic acid \\
\hline TFC & $89.67 \pm 2.516 \mathrm{mg} /$ gm equivalent to Rutin \\
\hline
\end{tabular}

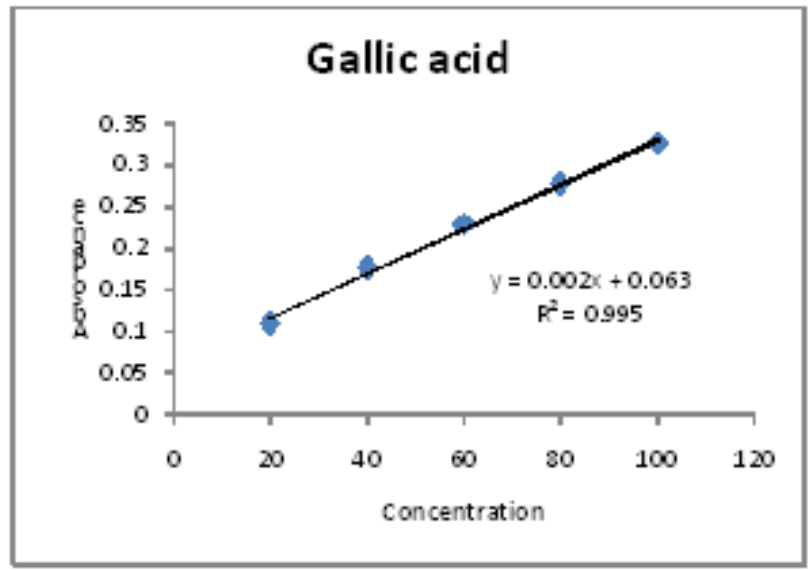

Figure 1: Graph of estimation of total phenolic content

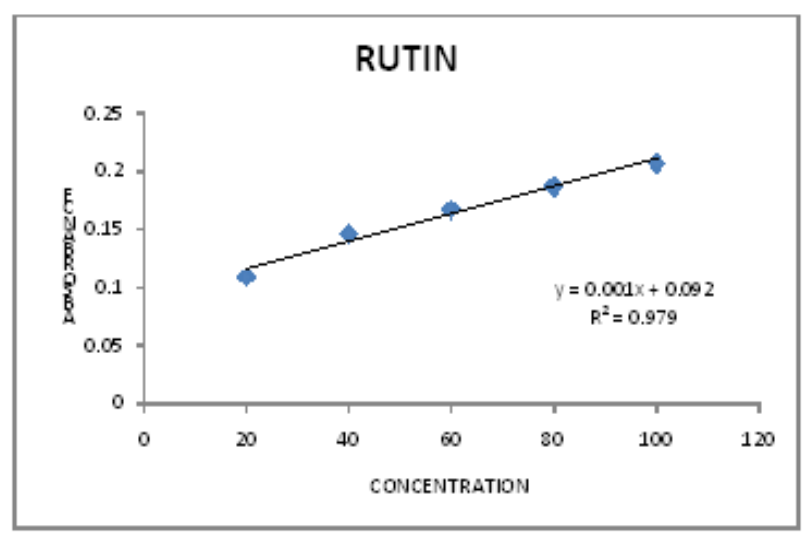

Figure 2: Graph of estimation of total flavonoids content

Table 4: Rf value of standard and extract

\begin{tabular}{|c|c|}
\hline Solvent system & Chloroform: methanol \\
\hline $\begin{array}{c}\text { Rf value of amentoflavone } \\
\text { standard }\end{array}$ & 0.232 \\
\hline $\begin{array}{c}\text { Rf value of amentoflavone in } \\
\text { extract }\end{array}$ & 0.234 \\
\hline
\end{tabular}

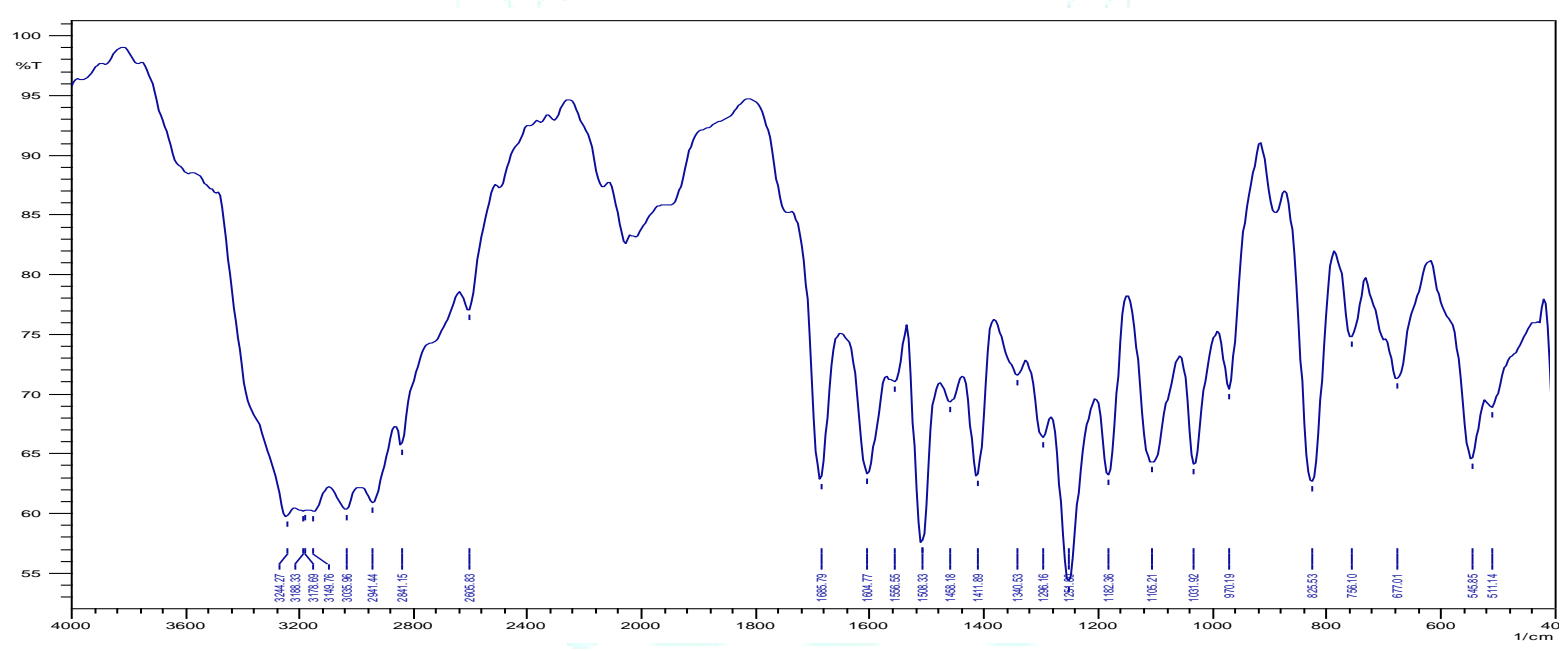

Fig. 3: Fourier transforms infrared spectra of the amentoflavone

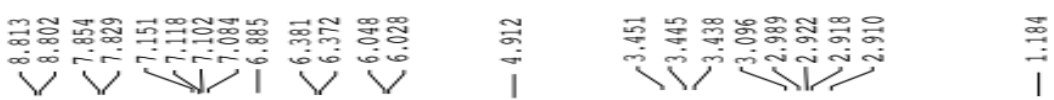

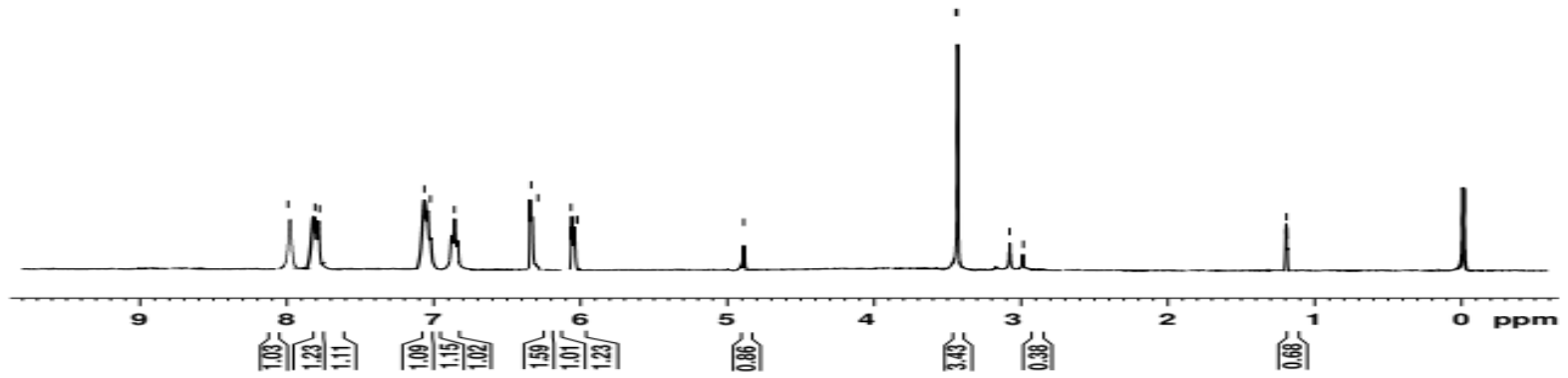

Fig. 4: 1HNMR Spectrum of the amentoflavone 


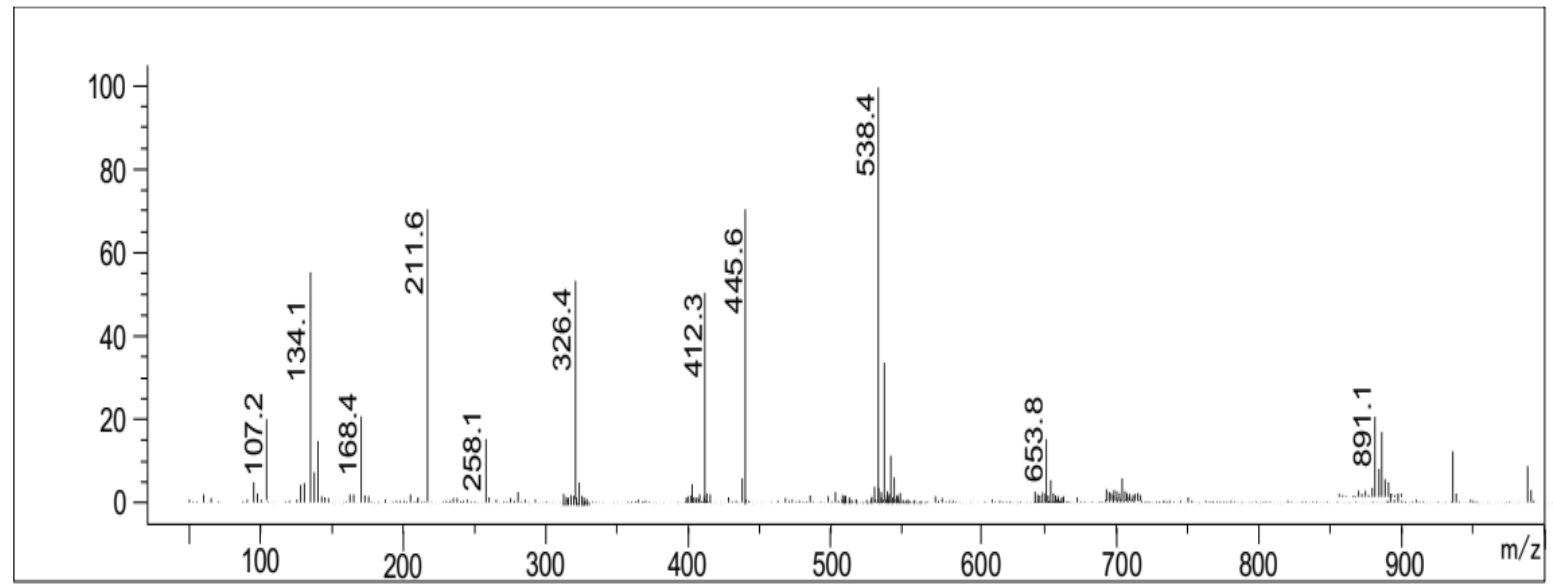

Fig. 5: Mass spectrum of the amentoflavone

\section{CONCLUSION}

From the above findings, amentoflavone were isolated from methanolic extract of the whole plant of S. bryopteris and chemical structures elucidated respectively. It was carried out by means of various physical (solvent extraction, TLC, Column chromatography) and spectral techniques.

\section{REFERENCES}

1. Rahmani AH, Aly SM, Ali H, Babiker AY, Srikar S, Khan AA. Therapeutic effects of date fruits (Phoenix dactylifera) in the prevention of diseases via modulation of anti-inflammatory, antioxidant and anti-tumour activity. Int J Clin Exp Med. 2014; 7:483-491.

2. Rahmani AH, Aly SM. Nigella sativa and its active constituent's thymoquinone shows pivotal role in the diseases prevention and treatment. Asian J Pharm Clin Res. 2015; 8:48-53.

3. Shukla AN, Srivastava S \& Rawat AKS. An ethnobotanical study of medicinal plants of Rewa district, Madhya Pradesh. Ind J Trad Knowl. 2010; 9:191-202.

4. Singh S, Dixit RD, Sahu TR. Ethnomedicinal uses of pteridophytes of Amarkantak, Madhya Pradesh. Ind J Trad Knowl. 2010; 4:392-395.

5. Silva GL, Chai H, Gupta MP, et al. Cytotoxic biflavonoids from Selaginella willdenowii. Phytochem. 1096; 40:129-134.

6. Miao N, Tao $\mathrm{H}$, Tong $\mathrm{C}$, et al. The Selaginella tamariscina (Beauv.) Spring complex in the treatment of experimental diabetes and its effect on blood rheology. Zhongguo Zhong Yao Za Zhi. 1996; 21:493-512.

7. Lee IS, Nishikawa A, Furukawa F, et al. Effects of Selaginella tamariscina on in vitro tumor cell growth, p53 expression, G1 arrest and in vivo gastric cell proliferation. Cancer Lett. 1999; 144:93-99.

8. Rojas A, Bah M, Rojas JI, et al. Spasmolytic activity of some plants used by the Otomi Indians of Queretaro for the treatment of gastrointestinal disorders. Phytomed. 1999; 6:367-371.

9. Ma SC, But PP, Ooi VE, et al. Antiviral amentoflavone from Selaginella sinensis. Biol Pharm Bull. 2001; 24:311-312.

10. Sah NK, Singh SN, Sahdev S, et al. Indian herb 'Sanjeevani' (Selaginella bryopteris) can promote growth and protect against heat shock and apoptotic activities of ultra violet and oxidative stress. J Biosci. 2005; 30: 499-505.

11. Cao Y, Tan NH, Chen JJ, et al. Bioactive flavones and biflavones from Selaginella moellendorffii Hieron. Fitoterapia 2010; 81:253-258.

12. Kang SS, Lee JY, Choi YK, et al. Neuroprotective effects of naturally occurring biflavonoids. Bioorg Med Chem Lett. 2005; 15:3588-3591.

13. Woo ER, Pokharel YR, Yang JW, et al. Inhibition of nuclear factor-kB activation by 20, 800-biapigenin. Biol Pharm Bull. 2006; 29:976-980.
14. Jing $Y$, Tang AZ, Liu J, et al. Effects of Selaginella doederleinii on human nasopharyngeal carcinoma TW03 cells in vitro and its mechanism. Zhong Yao Cai. 2009; 32:1864-1867.

15. Okigawa M, Hwa CW, Kawano N, Rahman W. Biflavones in Selaginella species. Phytochem. 1971; 10:3286-3287.

16. Arwa PS, Zeraik ML, Ximenes VF, Da Fonseca LM, Bolzani VS, Silva DHS. Redox-active biflavonoids from Garcinia brasiliensis as inhibitors of neutrophil oxidative burst and human erythrocyte membrane damage. J Ethnopharmacol. 2015; 174:410-418.

17. Abdallah HM, Almowallad FM, Esmat A, Shehata IA, AbdelSattar EA. Anti-inflammatory activity of flavonoids from Chrozophora tinctoria. Phytochem Lett. 2015; 13:74-80.

18. Park NH, Lee CW, Bae JH, Na YJ. Protective effects of amentoflavone on Lamin A-dependent UVB-induced nuclear aberration in normal human fibroblasts. Bioorg Med Chem Lett. $2011 ; 21: 6482-6484$.

19. Ndongo JT, Issa ME, Messi AN, Mbing JN, Cuendet M, Pegnyemb, DE Bochet, CG. Cytotoxic flavonoids and other constituents from the stem bark of Ochna schweinfurthiana. Nat. Prod. Res. 2015; 29:1684-1687.

20. Coulerie P, Nour M, Maciuk A, Eydoux C, Guillemot JC, Lebouvier N, et al., Structure-activity relationship study of biflavonoids on the Dengue virus polymerase DENV-NS5 RdRp. Planta Med. 2013; 79:1313-1318.

21. Hwang IS, Lee J, Jin HG, Woo ER, Lee DG. Amentoflavone stimulates mitochondrial dysfunction and induces apoptotic cell death in Candida albicans. Mycopathologia 2012; 173:207-218.

22. Zhang Z, Sun T, Niu JG, He ZQ, Liu Y, Wang F. Amentoflavone protects hippocampal neurons: Anti-inflammatory, antioxidative and antiapoptotic effects. Neural Regen. Res. 2015; 10:1125-1133.

23. Zheng XK, Liu CX, Zhai YY, Li LL, Wang XL. Feng WS. Protection effect of amentoflavone in Selaginella tamariscina against TNF$\alpha$-induced vascular injure of endothelial cells. Acta Pharm Sin. 2013; 48:1503-1509.

24. Vikram PK, Malvi R, Jain DK. Evaluation of analgesic and antiinflammatory potential of mimosa pudica linn. Int J Curr Pharm Res 2012; 4 (4):47-50.

25. Nayak A, Garg M, Jain S, Khan MA, Jain DK, Khan N. AntiUrolithiatic and Invitro-Invivo Anti-Oxidant Effects of Methanolic Extract of Thunbergia laurifolia on Ethylene GlycolInduced Kidney Calculi in Rats. Sch Acad J Pharm. 2019; 8 (3):94-104.

26. Joshi S, Parkhe G, Aqueel N, Dixit N, Jain DK. Estimation of total phenolic, total flavonoids and total protein content of hydroalcoholic extract of Anacyclus pyrethrum. Pharmacologyonline 2019; 1:27-33.

27. Jain DK, Nayak A, Patel P, Jain S, Khan MA. Appraisal of in vitro Antioxidant and in vivo Anti-Inflammatory Activities of Various Extracts from the Fruits of Vitis vinifera L. Sch Acad J Pharm 2019; 8 (3):86-93. 